\title{
Nutrient cycling and plant dynamics in estuaries: A brief review
}

\author{
Mogens R. Flindt ${ }^{\mathrm{a}}$, Miguel Ângelo Pardal ${ }^{\mathrm{b} *}$, Ana Isabel Lilleb $\varnothing^{\mathrm{b}}$, Irene Martins ${ }^{\mathrm{b}}$, \\ João Carlos Marques b \\ ${ }^{a}$ Freshwater Biological Laboratory, University of Copenhagen, Helsingørsgade 51, Dk-3400 Hillerød, Denmark. \\ ${ }^{b}$ IMAR (Institute of Marine Research), Department of Zoology, University of Coimbra, 3004-517 Coimbra, Portugal. \\ * Corresponding author (fax: +351 39 823603; e-mail: macpimar@gemini.ci.uc.pt)
}

Received February 26, 1998; revised December 30, 1998; accepted February 26, 1999

\begin{abstract}
Eutrophication of European estuaries due to massive nutrient loading from urban areas and diffuse runoff from extensively cultivated land areas is analysed. Consequences for the ecology of estuaries, namely changes in plant species composition, which also affects heterotrophic organisms, are approached based on examples showing that the result is often a fundamental structural change of the ecosystem, from a grazing and/or nutrient controlled stable systems to unstable detritus/mineralisation systems, where the turnover of oxygen and nutrients is much more dynamic and oscillations between aerobic and anaerobic states frequently occur. Several relevant aspects are examined, namely the influence of rooted macrophytes on nutrient dynamics, by comparing bare bottom sediments with eelgrass covered sediments, primary production and the development of organic detritus, and hydrodynamics and its relations to the spatial distribution of macrophytes in estuarine systems. (C) 1999 Éditions scientifiques et médicales Elsevier SAS
\end{abstract}

Estuaries / eutrophication / macrophytes and nutrient dynamics

\section{ESTUARINE EUTROPHICATION AND ITS EFFECTS ON PLANT COMMUNITIES}

The physical and chemical dynamics and the ecology of shallow estuarine areas are strongly influenced by the runoff of freshwater from the land and the exchange of water with the adjacent open sea. The freshwater input influences estuarine hydrography by creating salinity gradients and stratification, and assures large transport of silt, organic material and inorganic nutrients to the estuaries. The open marine areas impose large scale physical and chemical forcing on the estuarine ecosystem, due to tide and windgenerated water exchange. This pulse created by the boundary also insures a large transport of organic material and nutrients subsidising primary and secondary production in the estuarine area [3].

The most characteristic physical feature of estuaries is the shallow water column, often well mixed and thus resulting in tight coupling between benthic and pelagic processes. Organic matter is produced by a large variety of primary producers either connected to the sediment such as benthic microalgae, macroalgae and rooted macrophytes or in the pelagic as phytoplankton.
Efficient water column mixing and frequent resuspension events ensure fast vertical transport of organic and inorganic matter integrating the pelagic and benthic food webs and the biogeochemical processes.

During the last 40 years, the eutrophication of our estuaries has increased due to massive nutrient loading from urbanised areas and diffusive runoff from extensively cultivated land areas. This has made estuaries among the most eutrophied ecosystems (figure 1). This increased nutrient loading has severe consequences for the ecology of estuaries, due to changes in plant composition, which consequently affects heterotrophic organisms, specialised in living on this production (see for example [7, 21, 25, 26, 31]).

Before eutrophication, estuaries were ecosystems dominated by seagrasses and brown macroalgae which formed dense standing stocks down to 5-10 $\mathrm{m}$ depth where the annual production could reach up to 500-1 $000 \mathrm{~g} \mathrm{C} \cdot \mathrm{m}^{-2}$ [31]. Most nutrients were in leaves and plant roots during the growth season insuring a stable environment for the fauna and its relatively high biodiversity. These areas also contained a large number of opportunistic macroalgae, but their biomass 


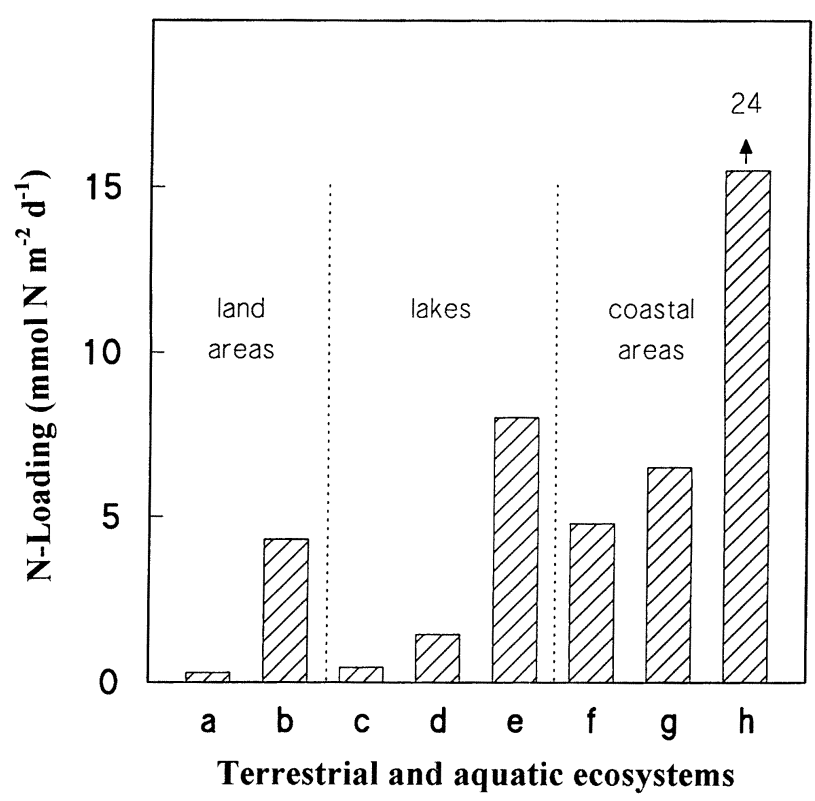

Figure 1. Daily nitrogen loadings of a variety of Danish terrestrial $(\mathrm{a}, \mathrm{b})$, freshwater $(\mathrm{c}-\mathrm{e})$ and estuarine ecosystems $(\mathrm{f}-\mathrm{h})$ : a, unfertilised land areas; b, agricultural areas; c, Lake Esrum; d, Lake Fures $\varnothing ;$ e, Lake Glumsø; f, Limfjord; g, Roskilde Fjord; h, Norsminde Fjord.

were kept relatively low, probably because they were more heavily grazed than the rooted vegetation [15].

As a consequence of nutrient enrichment, phytoplankton and opportunistic macroalgae growth were stimulated (figure 2). This affected the light climate, and the rooted macrophytes therefore became extinct in the deeper areas of these systems and forced into very shallow areas (figure 3). In Roskilde Fjord (Denmark) due to this process, the eelgrass coverage decreased from nearly $100 \%$ in the early fifties to about 5 to $10 \%$ within the next 20 to 30 years. This change in plant community composition is well demonstrated in Roskilde Fjord [6] where the nitrogen loading and concentration are highest in the inner part and reduced throughout the system (figure 4).

The extinction of seagrasses in more shallow areas also occurred. This was related to frequent episodes of anoxia. As a result of nutrient loading, fast growing filamentous and sheet-like macroalgae started to appear in large biomasses [18]. The algae were able to grow to abundances of $1000-2000 \mathrm{~g} \mathrm{dwt} \cdot \mathrm{m}^{-2}[29$, 34]. With these densities, the algae cover the bottom in thick mats. The photosynthetic production in the lower part of the mat is limited by light. In such situations, the respiratory oxygen demand easily exceeds the

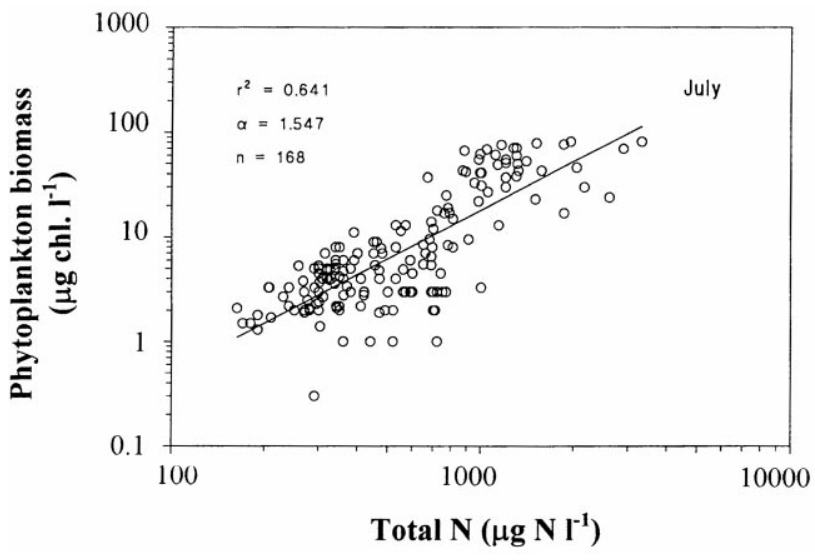

Figure 2. Regression between total nitrogen concentration and the phytoplankton biomass in the summer period.

photosynthetic oxygen production and when this situation lasts for several days, oxygen depletion and $\mathrm{H}_{2} \mathrm{~S}$ poisoning kill the algae. The process is selfaccelerating, due to an increasing microbial mineralisation of the dead algae. An efflux of nutrients follows the degradation, which subsequently stimulates the growth of phytoplankton and still living macroalgae [34]. After severe collapse situations, rooted macrophytes are killed and growth limiting nutrients, which previously were bound in the macrophytes, become available for further growth of phytoplankton and opportunistic macroalgae. Furthermore, this results in the death of the associated fauna of mussels

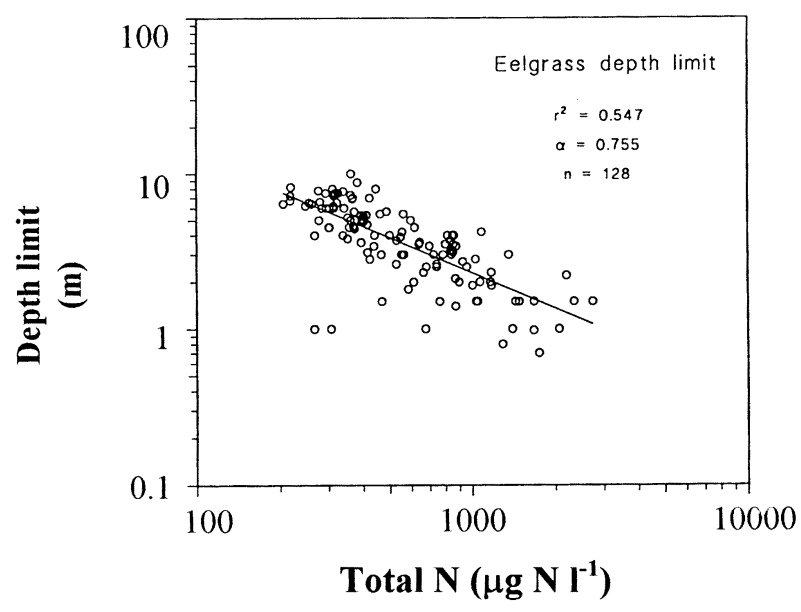

Figure 3. Regression between total nitrogen concentration and eelgrass depth limit in the summer period. 


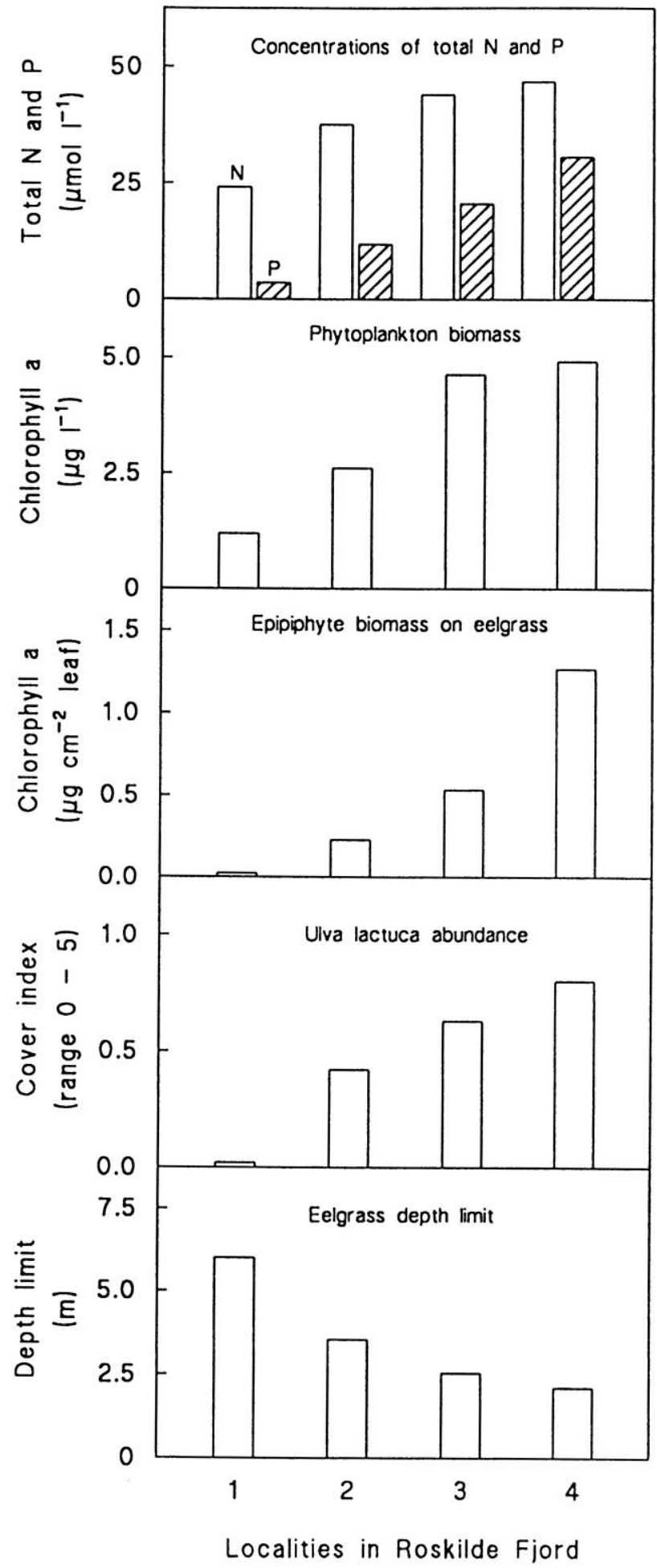

that do not have the ability to escape anoxic periods. If the anoxic event occurs in areas with high mussel biomass, the degradation of their soft part may increase the internal nutrient loading with amounts of nitrogen and phosphorus comparable with the annual external loading of the system. And even more seriously, the potential grazer control of the phytoplankton is lost for several years. Rooted macrophytes often serve as shelter and recruitment environment for mobile grazers, such as Isopods and Amphipods, which move to surrounding habitats to feed at night. Hence, a decline in rooted macrophyte coverage may reduce grazer control on opportunistic macroalgae populations (see also [1]).

Geertz-Hansen and Sand-Jensen [14] found unchanged growth rates for Ulva sp. along an eutrophication gradient in a Danish estuary. The authors showed that grazing was negatively correlated with the eutrophication gradient and that grazing was an important factor in controlling biomass accumulation of the free-floating macroalgae.

The occurrence of anoxic periods is frequently explained as a result of increased production of organic matter within the ecosystem due to stimulation of phytoplankton. But, in general, this is not the case, eutrophication does not stimulate the total primary production per unit area but rather shifts the main productivity from the benthic to the planktonic community (figure 5) [33]. This means that oxygen production is restricted to the surface zone and thereby spatially and temporally separated from oxygen consumption: spatially separated because the oxygen consumption is linked to the mineralisation of the sedimented phytoplankton at the bottom; and temporally separated because this mineralisation takes place when the primary producers are dead.

The result is a fundamental structural change of the ecosystem, from a grazing and/or nutrient controlled stable system to an unstable detritus/mineralisation

Figure 4. Changes in plant communities along a eutrophication gradient in Roskilde Fjord (Denmark). Mean concentrations of total nitrogen and total phosphorus, mean phytoplankton biomass, mean epiphyte biomass on eelgrass during summer, abundance of Ulva lactuca, and depth penetration of eelgrass (data from Borum $[4,5]$ and Hansen [17]). With increasing nutrient richness, phytoplankton and especially epiphyte biomass increase. The abundance of the fast-growing macroalgae, $U$. lactuca, also increases while depth penetration of eelgrass decreases due to a reduced light climate. 


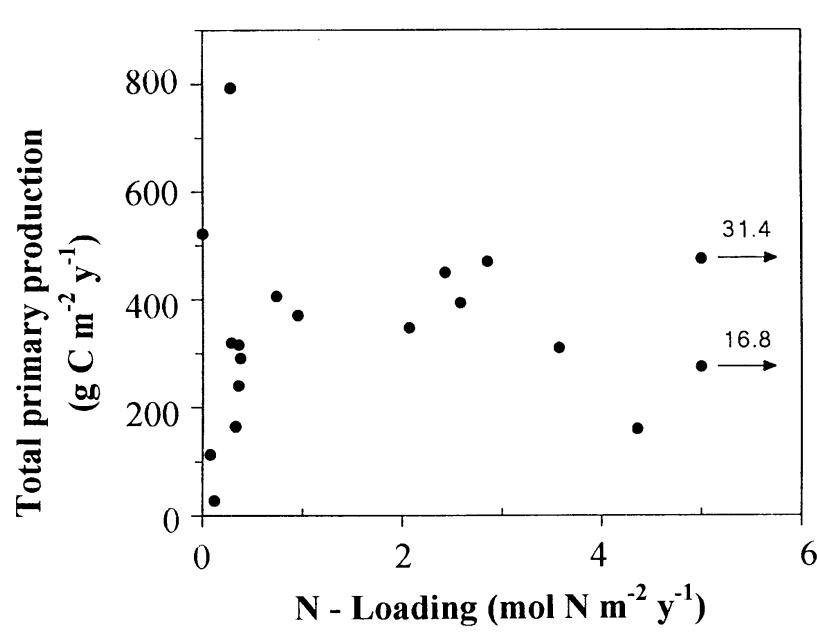

Figure 5. Regression between yearly nitrogen loading and total primary production.

system, where the turnover of oxygen and nutrients is much more dynamic [38] and oscillations between aerobic and anaerobic states frequently occur.

In most estuaries, seagrasses are now extinct from the deeper part and, therefore, only play a limited role as primary producers. These changes have huge impacts at the system level because several complicated feedback mechanisms, positive as well as negative, between the rooted vegetation and hydraulic conditions and nutrient dynamics are reversed or out of function. In the next part of this paper, we will look at some of these feedback mechanisms to have an idea of their potential role in reversing this development, so that seagrasses will return as the dominating plant in estuaries.

\section{ROOTED MACROPHYTES INFLUENCE NUTRIENT DYNAMICS}

Submersed rooted macrophytes link the nutrients in sediments with the overlying water. This linkage has potentially important implications for nutrient cycling within such systems. Sediments can provide a major source of nutrient supply for submersed macrophytes [2]. Porewater concentrations of inorganic nitrogen and phosphorus are often one to three decades higher than in the water column, which justifies the preference for taking up these nutrients from the sediment. Several authors $[9,10,36]$ have shown that rooted submersed macrophytes are able to take up almost all the needed $\mathrm{P}$ from the sediment. Information on the relative contribution of sediment porewater and the overlying water column to the $\mathrm{N}$ economy of rooted macrophytes is rather limited. A few experiments with ${ }^{15} \mathrm{~N}$ demonstrated that, submersed macrophytes could take up inorganic $\mathrm{N}$ from both porewater and the water column [27, 28, 35].

In a study done by Flindt [13], the nutrient dynamic in bare bottom sediment was compared to the dynamics in eelgrass covered sediment (figure 6). The initial biomass of eelgrass was $130 \mathrm{~g} \mathrm{dwt} \cdot \mathrm{m}^{-2}$. The biomass expressed in units of carbon and nitrogen was 44 and $1.47 \mathrm{~g} \cdot \mathrm{m}^{-2}$, respectively. The production of Zostera marina during the study period was $151 \mathrm{~g} \mathrm{dwt} \cdot \mathrm{m}^{-2}$ and its relative growth rate was $0.02 \mathrm{~d}^{-1}$.

The most pronounced difference in the phosphorus dynamics between the two systems was that the bare bottom sediment phosphate profile showed values of 100-200 $\mathrm{mg} \mathrm{PO}_{4}^{3--}-\mathrm{P} \cdot \mathrm{m}^{-2}$ higher than the plant system (figure $6 a, 6 d$ ). The much stronger phosphate gradient near the rhizosphere was caused by increased P-sorption due to release of oxygen and P-uptake by the plant roots in the vegetated sediment.

In addition, the ammonia profiles showed differences in development. The depletion of ammonia in the water column was much faster in the vegetated system (figure 6e). The depth-integrated pool for ammonia in the bare bottom system was twice the amount of the vegetated system, in spite of an initially wellestablished nitrification process in the water phase of the bare bottom system. This indicates that eelgrass had a high $\mathrm{NH}_{4}^{+}$uptake rate as well as the existence of a tight coupling between the ammonification and the nitrification processes.

The most pronounced difference between the two systems were the nitrate profiles. The constant level of nitrate down to $10-\mathrm{mm}$ depth in the bare bottom system indicates the depth of the oxic zone, whereas the penetration in the vegetated sediment reached down to $72-\mathrm{mm}$ depth with a maximum at $50 \mathrm{~mm}$. This was reflected in the integrated amounts of nitrate, where the pool in the vegetated sediment was four to eight times higher than in the bare bottom system, which indicate that the production of nitrate is highest in the vegetated sediment. The high ammonia pool in the sediment of the bare bottom system, most likely reflects the oxygen limitation of the nitrification. The occurrence of a distinct increase in maximum nitrate levels (figure $6 f$ ) indicates that the production of nitrate was higher than the denitrification. This is in general not the case, as nitrifying bacteria are slow growing chemo-autotrophic organisms that can easily be exceeded by an active population of denitrifying 

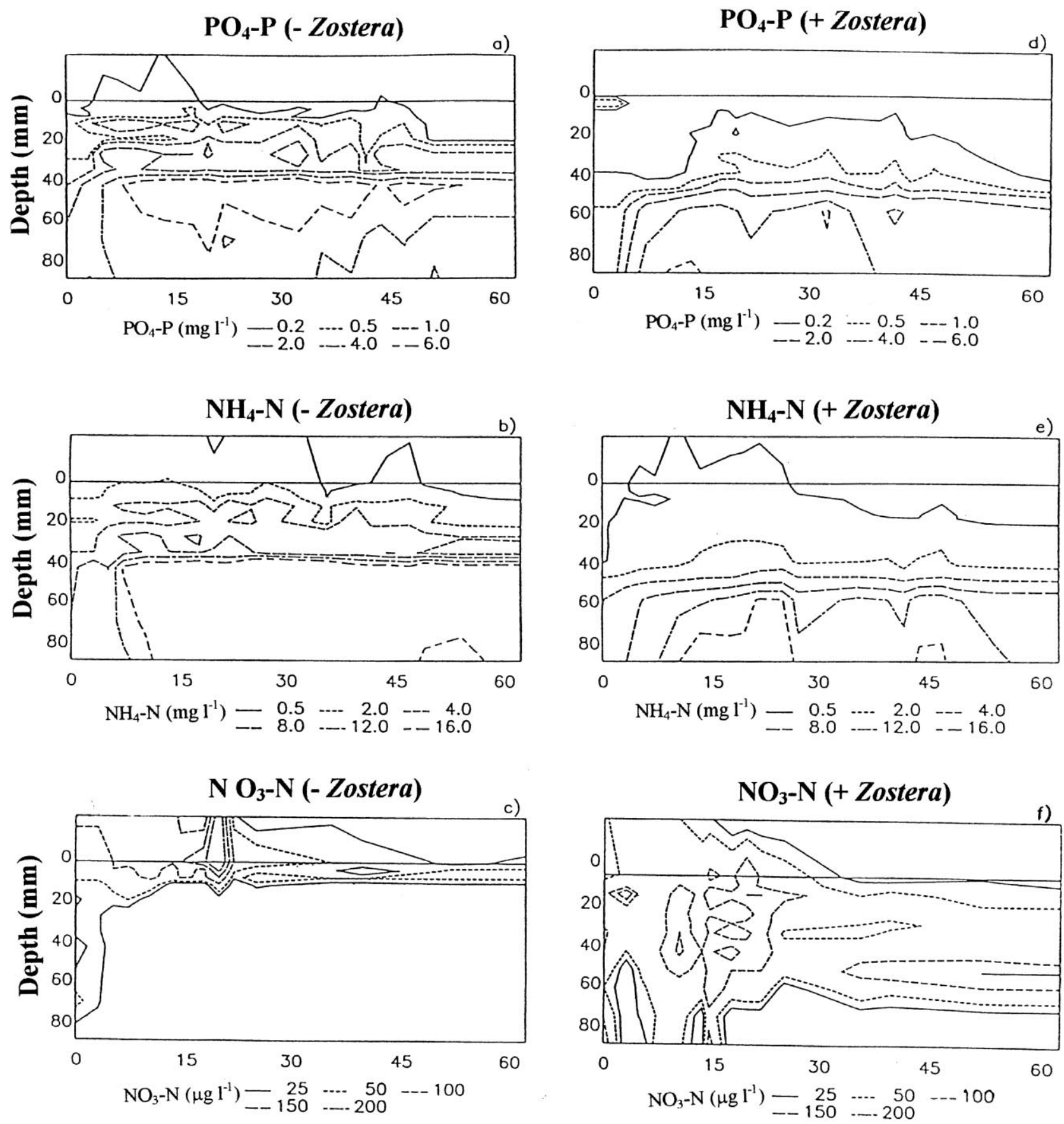

Day number

Day number

Figure 6. Temporal and vertical variations in the water column and porewater concentrations of $\mathrm{PO}_{4}^{3-}-\mathrm{P}(\mathrm{a}, \mathrm{d}), \mathrm{NH}_{4}^{+}-\mathrm{N}(\mathrm{b}, \mathrm{e})$ and $\mathrm{NO}_{3}^{-}-\mathrm{N}(\mathrm{c}, \mathrm{f})$ during the 2-month study period. 
Table I. Phosphorus mass balance in the bare bottom and the Zostera marina experiment.

\begin{tabular}{lcc}
\hline & $\begin{array}{c}\text { Bare bottom } \\
\mathrm{mg} \mathrm{P} \cdot \mathrm{m}^{-2}\end{array}$ & $\begin{array}{c}\text { Zostera } \text { area } \\
\mathrm{mg} \mathrm{P} \cdot \mathrm{m}^{-2}\end{array}$ \\
\hline $\begin{array}{l}\text { Total P initial } \\
\quad \text { particulate + dissolved P) }\end{array}$ & 3096 & 2972 \\
$\begin{array}{l}\text { Total P final } \\
\quad \text { particulate + dissolved P) }\end{array}$ & 3244 & 2417 \\
$\begin{array}{l}\text { Zostera marina } \text { P-uptake } \\
\text { Mass balance }\end{array}$ & 0 & 331 \\
\hline
\end{tabular}

bacteria. This situation may indicate that nitrification was favoured by excessive concentrations of both $\mathrm{O}_{2}$ and $\mathrm{CO}_{2}$.

The mass balance results (tables I, II) from the experiment shows that the net denitrification in the eelgrass system $\left(1.5 \mathrm{mmol} \cdot \mathrm{m}^{-2} \cdot \mathrm{d}^{-1}\right)$ was close to twice the rate in the bare bottom system $(0.88$ $\left.\mathrm{mmol} \cdot \mathrm{m}^{-2} \cdot \mathrm{d}^{-1}\right)$. The rates were within the same range as in Caffrey and Kemp [8], who measured potential denitrification rates in a $Z$. marina covered sediment. The increase in oxidised surface area in the vegetated sediment compared to the bare sediment stimulates nitrification rate and subsequently denitrification. The denitrification may further be stimulated by highquality dissolved organic carbon released by the roots.

It has to be stated that during the last year, studies based on ${ }^{15} \mathrm{~N}$ measurements contradict these results. A possible explanation could be that down-mixing of large volume of ${ }^{15} \mathrm{~N}$ may disturb the developed profiles, but that making experiments under mass balance control more reliable due to the use of in situ techniques, as in the present experiment allows nondestructive sampling.

The phosphorus dynamics were newly studied in the Mondego estuary at several intertidal stations on

Table II. Nitrogen mass balance in the bare bottom and the Zostera marina experiment.

\begin{tabular}{lcc}
\hline & $\begin{array}{c}\text { Bare bottom mg Zostera } \text { area mg } \\
\mathrm{N} \cdot \mathrm{m}^{-2}\end{array}$ & $\mathrm{~N} \cdot \mathrm{m}^{-2}$ \\
\hline $\begin{array}{l}\text { Total N initial } \\
\quad \text { particulate + dissolved N) }\end{array}$ & 5293 & 5237 \\
$\begin{array}{l}\text { Total N final } \\
\quad \text { particulate + dissolved N) }\end{array}$ & 4547 & 1815 \\
$\begin{array}{l}\text { Zostera marina } \mathrm{N} \text {-uptake } \\
\text { Mass balance (net denitrification) }\end{array}$ & -747 & 2090 \\
\hline
\end{tabular}

a seasonal scale. These stations differed with respect to nutrient loadings, hydraulic conditions, plant cover and organic content in the sediment, porewater profiles of phosphate, ammonia and nitrate. At each station, the nutrient dynamics was followed by measuring oxygen dynamics, dissolved organic carbon, phosphate, ammonia, nitrate and physical parameters such as salinity, temperature, sediment organic matter, sediment water content, pool volume and pool area (see also [20, 24]).

Very pronounced differences in porewater concentrations of dissolved inorganic nutrients existed between the stations during the summer measurements (figure 7). Comparing bare bottom sandy and muddy stations, the concentrations of phosphate never increased above $0.6 \mathrm{mg} \mathrm{PO}{ }_{4}^{3-}-\mathrm{P} \cdot \mathrm{L}^{-1}$ in the sandy station, while it reached a concentration of more than $4 \mathrm{mg} \mathrm{PO}{ }_{4}^{3-}-\mathrm{P} \cdot \mathrm{L}^{-1}$ in the muddy porewater. In the Spartina maritima covered muddy sediments, phosphate was low in the rhizosphere $(0-8 \mathrm{~cm}$ depth) at the same depth. Deeper in the sediment $(8-15 \mathrm{~cm}$ depth), the concentrations equalised. Comparing effluxes of phosphate during the life-span of the pools, the muddy bare bottom pools had the highest efflux of $30 \mathrm{mg} \mathrm{PO}{ }_{4}^{3}-\mathrm{P} \cdot \mathrm{m}^{-2} \cdot \mathrm{d}^{-1}$ while the mean efflux in the Spartina pools was $20 \mathrm{mg} \mathrm{PO} \mathrm{PO}_{4}^{3-}-\mathrm{P} \cdot \mathrm{m}^{-2} \cdot \mathrm{d}^{-1}$ and only about $3 \mathrm{mg} \mathrm{PO}{ }_{4}^{3-}-\mathrm{P} \cdot \mathrm{m}^{-2} \cdot \mathrm{d}^{-1}$ in the sandy areas.

Adsorption/desorption isotherms were also studied. In the muddy Spartina rhizosphere, the highest adsorption capacity was $140 \mu \mathrm{g} \mathrm{PO}_{4}^{3-}-\mathrm{P} \cdot \mathrm{g}^{-1} \mathrm{dwt}$ sediment,

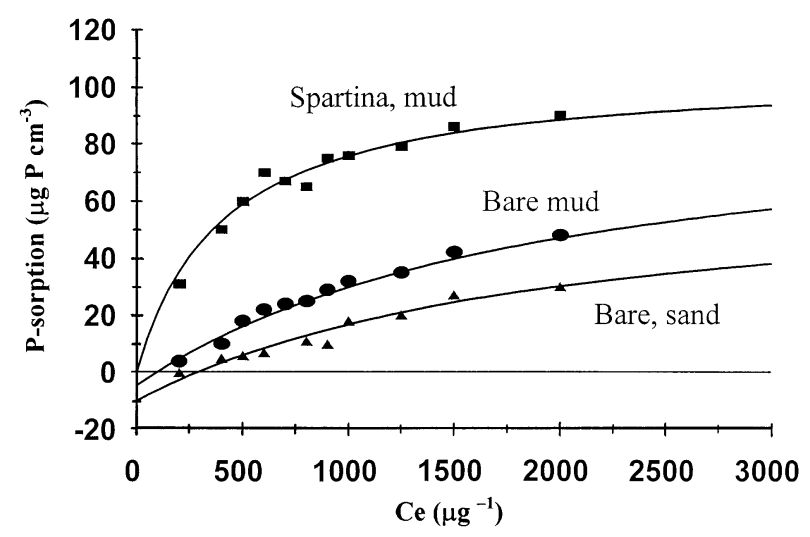

Figure 7. Porewater profiles of phosphate from sandy sediments, bare bottom muddy sediments and from Spartina marina covered muddy sediments during a summer day (1997). 
while the bare muddy area in the same sediment depth had a capacity of $80 \mu \mathrm{g} \mathrm{PO}_{4}^{3-}-\mathrm{P} \cdot \mathrm{g}^{-1} \mathrm{dwt}$ sediment. The sandy sediment showed a capacity of only $30 \mu \mathrm{g} \mathrm{PO}_{4}^{3-}-\mathrm{P} \cdot \mathrm{g}^{-1} \mathrm{dwt}$ sediment. The difference between stations was significant $(P<0.01)$. Altogether, these studies indicated that Spartina maritima is able to control phosphorus dynamics in the intertidal sediment.

Conclusively, rooted vegetation potentially enhances denitrification and thus minimise the efflux of ammonia to the water column, which will reduce competition from opportunistic macroalgae and phytoplankton. The enhanced phosphate adsorption capacity in the rhizosphere also insures low phosphate effluxes. Furthermore, it is well established that seagrasses are able to modify seasonal nutrient cycling by storing nitrogen during the growth period and by reallocating nutrients from old to new leaves [32] before senescence. With these mechanisms, seagrasses keep nutrient dynamics very close to the rhizosphere. Depending on the nutrient status of the sediment, plants are able to adjust their biomass with respect to the above/below-ground ratio. When growing in sediments with high availability of dissolved inorganic nutrients, plants reduce root biomass, and vice versa when they live in nutrient poor sediments; hence, plants have to search for sufficient nutrient in the sediment for growth purposes [2]. Thus, the mechanisms will be even more pronounced for plants covering nutrient poor sediments. Functionally, it will improve the light climate for the rooted vegetation and may be a mechanism that accelerates the return of seagrasses to deeper parts of estuaries.

\section{PRIMARY PRODUCTION: THE DETRITUS PATHWAY}

The knowledge on macrophyte production is well established but only a little is known about the fate of the production. Although, some birds are reported to graze on rooted macrophytes [37], the grazing is seldom extensive in temperate areas [23, 30]. Instead, the leafs are sloughed with ageing or at the end of the growing season, or they are broken or removed during periods of violent wave motion. Thus, most of the production enters detrital food webs.

More extensive grazing appears on opportunistic macroalgae, where the isopod Idotea sp. in some periods of the growth season is able to control the Ulva lactuca biomass [15]. On the other hand, it was found that $40 \%$ of the $U$. rigida biomass was degraded in 15 days, but quantitative knowledge about the mineralisation rates is very scarce.

Several experiments have been made on the decomposition of Zostera marina and they all found very low mineralisation rates $[11,12,22,23]$. At this long time-scale, seagrass detritus undergoes physical, chemical and biotic fragmentation, bacterial mineralisation and chemical transformation. The amount of structural parts, such as lignin and cellulose, and the nutrient status of the plant $(\mathrm{C}: \mathrm{N}: \mathrm{P}$ ratio), affect these processes and the integrated mineralisation rates. The long degradation period comprises several different temporal phases [16]. The first phase is the initial leaching of easily degradable low molecular cellular substances. It is followed by an intermediate phase where the decomposition of the structural parts is initiated and finally, in the last phase, the slow degradation of the more stable structural plant material occurs.

Opportunistic macroalgae have no structural parts with high contents of lignin and cellulose like eelgrasses do, which causes a difference in the C:N ratio among the two plants: 20/30 for Zostera and $7 / 15$ for Ulva. These explain why eelgrass has degradation rate constants ranging from 0.001 to $0.018 \mathrm{~d}^{-1}$ [19], whereas the rate constants for Ulva vary from 0.02 to $0.26 \mathrm{~d}^{-1}$. The consequence of these nutritional and morphological differences is that Zostera enters all three decomposition phases, while Ulva decomposes during the first two phases. The mineralisation rates for both species vary considerably during the decomposition phases, with the highest rates during the initial phase.

In this study, we compared degradation rates and nutrient regeneration of newly sloughed leaves of Z. marina and green fresh U. lactuca during aerobic and anaerobic conditions. Leaching of dissolved organic matter from Zostera leaves was very fast. This event completely dominated the nutrient dynamics of the experiment during most of the study period. A few days after the leaching, the phosphate and ammonium concentrations increased dramatically in the water column. After the leaching process, the slow development in the ammonia and phosphate concentrations indicated that the next phase of plant degradation had started. By recognising these two different phases in the Zostera experiment, it was possible to calculate the mineralisation rate constants of $\mathrm{C}, \mathrm{N}$ and $\mathrm{P}$ for each period (figure $8 a-c$ ). Even the initial C-mineralisation rates of Zostera were very low indicating a degradation period of about 1 year independent of the amount of biomass, where the nitrogen and phosphorus min- 

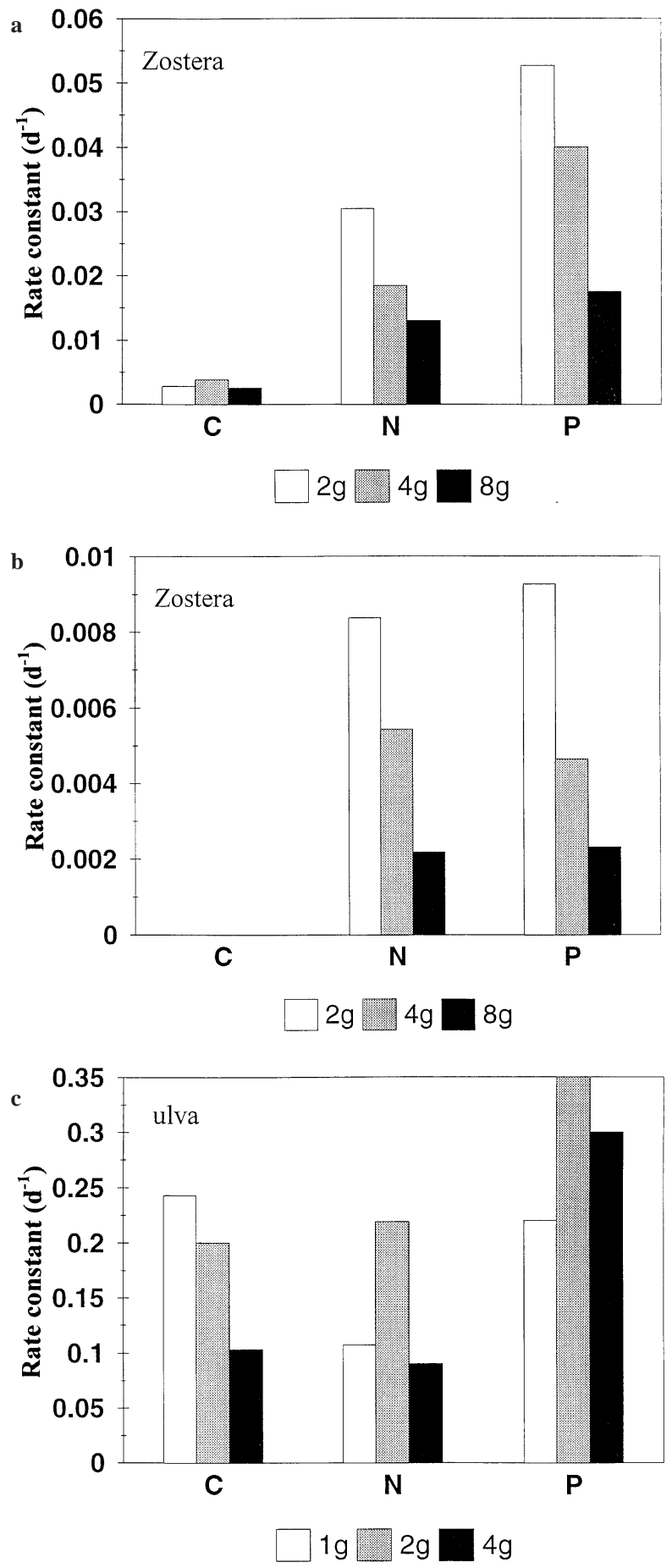

Figure 8. Calculated mineralisation rate constants for $\mathrm{C}, \mathrm{N}$ and $\mathrm{P}$ during the initial leaching phase of Zostera $(\mathrm{a}, \mathrm{b})$ and for Ulva (c). The rate constant for $\mathrm{N}$ and $\mathrm{P}$ include both dissolved organic $\mathrm{N}$ and $\mathrm{P}$ and particulate organic $\mathrm{N}$ and $\mathrm{P}$, whereas the rate constant for $\mathrm{C}$ only is based on the mineralisation of dissolved organic carbon (DOC). eralisation takes 1-3 and 1-2 months, respectively. Nitrogen and phosphorus mineralisation decreases to 4-14 months for $\mathrm{N}$ and 3-11 months for $\mathrm{P}$ after the leaching phase, where the mineralisation is dominated by the degradation of structural material. The initial degradation of Ulva was much faster, ranging between 4 and $10 \mathrm{~d}$ for DOC, 5 and $11 \mathrm{~d}$ for nitrogen and 3 to $5 \mathrm{~d}$ for phosphorus. Differences in the DOC quantitative dynamics in the two plant experiments were also evident. In the Ulva experiment, the amount of initial leaking DOC represented more than $50 \%$ of the carbon biomass, while in the Zostera experiment, it was only about $5 \%$ of the biomass. This explains the difference in the initial rate of degradation of the two plant components. The evolution of the N/P ratio in both plant experiments revealed that phosphate was mineralised faster than nitrogen, where the temporal delay in the nitrogen mineralisation was about 1 week in the Ulva experiment and close to 2 weeks during the decay of Zostera. This temporal uncoupled mineralisation of the elements may be important for the ecological response to a major plant decay situation, depending on whether the system is growth limited by nitrogen or phosphorus.

The fast degradation of Ulva is shown to be enhanced by colonisation of large amounts of bacteria within the first $24 \mathrm{~h} \mathrm{[40].} \mathrm{The} \mathrm{consequence} \mathrm{is} \mathrm{that} \mathrm{the}$ re-aeration influx of oxygen is unable to satisfy the oxygen consumption during the initial phase. The resulting anoxia and sulphate respiration create high fluxes of free sulphide into the water column. The shift from production to decomposition results in substantial changes in nutrient recycling in macroalgal dominated systems [39]. During the growth period, dissolved inorganic nitrogen and phosphorus are kept at low levels due to macrophyte uptake, but during the decomposition phase, nitrogen and phosphorus are rapidly recycled to the water column. The same degradation pattern is not observed in rooted macrophyte beds, most probably because of a tighter temporal and spatial coupling in the nutrient recycling linked to a much slower plant mineralisation rate [39]. The lower turnover of nutrients in beds with rooted vegetation results in a lower oxygen demand for plant degradation which reduces the risk of excessive sulphide production. The consequence of reduced eutrophication will be a less dynamic system in favour of the slow growing rooted macrophytes. In table III, we summarise the most probable states of a number of essential processes in estuaries as a function of eutrophication and of the dominating plant components. 
Table III. The state of essential processes in relation to eutrophication and the dominating plant components.

\begin{tabular}{llll}
\hline \multirow{2}{*}{ Effects } & \multicolumn{2}{c}{$1950 \longrightarrow$ 1994 } \\
\cline { 2 - 4 } & $\begin{array}{l}\text { Rooted } \\
\text { vegetation }\end{array}$ & $\begin{array}{l}\text { Opportunistic } \\
\text { macroalgae }\end{array}$ & Phytoplankton \\
\hline Mineralisation & $100-700 \mathrm{~d}$ & $5-21 \mathrm{~d}$ & $2-15 \mathrm{~d}$ \\
N-turnover & $1-2 \times \mathrm{Y}^{-1}$ & $10 \times \mathrm{Y}^{-1}$ & $10-20 \times \mathrm{Y}^{-1}$ \\
$\mathrm{O}_{2}$-dynamic & stable & unstable & unstable \\
Resuspension & low & intermediate & high \\
Nitrification & high & intermediate & low \\
Denitrification & high & intermediate & low \\
P-adsorption & high & low & low \\
Efflux of DIN, DIP & low & high & high \\
Turbidity & low & intermediate & high \\
Export (N, P) & low & high & high \\
\hline
\end{tabular}

\section{MACROPHYTES AND THE HYDRAULIC REGIME}

The collapse events are most often observed in areas with relatively calm hydraulics. In hydraulic dynamic areas, advective transport may be the most important process that controls the spatial and temporal distribution of macroalgae. Depending on the tidal amplitude, depth, cohesiveness of plant material, current velocity, and wind- and wave-induced vertical turbulence, plants growing in shallow areas are suspended in the water column and transported out and eventually settled in deeper areas. Furthermore, collapse situations are avoided in hydraulic dynamic areas because oxic conditions are re-established by water exchange and mixing.

Convective transport is of major importance because it may regulate the oxic conditions in estuaries with high opportunistic macroalgae productivity. The total mass balance of nutrients may also be significantly affected by the advective transport of nutrients bound in macroalgae biomass. This point is overlooked if mass balance calculations are solely based on traditional water quality parameters such as dissolved nutrients and small-sized suspended particles.

As pointed out above, it is obvious that advective transport processes may be important for the control of non-attached macroalgae biomass and thereby for the control of the whole ecosystem structure in estuaries with high macroalgal productivity. However, very little is known on the quantitative aspect of this phenomenon.

The objective of the following case study was to reveal some of these aspects. It was done in the Venice
Lagoon near the Malamocco inlet, S. Pietro Octagonal and Pellestrina Island. The study site was a shallow area (average depth about $1 \mathrm{~m}$ ) surrounded by channels. The area was characterised by strong currents influenced by tidal excursions and wind action. These physical factors determined the chemical characteristics in the water column and in the sediment and thereby also influenced the composition of the biological community. Due to the high water exchange with the Adriatic sea, aerobic conditions at the sediment surface were never compromised and the water quality was typical of an oligotrophic estuary.

During the study period, we measured the relative importance of growth, grazing, sporulation and advective transport in the regulation of the standing stock of the different macrophytes. In addition, we estimated relative contribution to the total advective transport of carbon, nitrogen, and phosphorus for each fraction of macroalgae, particulate and dissolved organic and inorganic matter. The standing biomass of Ulva sp. in the study area decreased from $0.82 \mathrm{~kg} \mathrm{wwt} \cdot \mathrm{m}^{-2}$ to $0.1 \mathrm{~kg} \mathrm{wwt} \cdot \mathrm{m}^{-2}$ during the study period, while the biomass of Chaetomorpha sp. decreased from $0.45 \mathrm{~kg} \mathrm{wwt} \cdot \mathrm{m}^{-2}$ to $0.03 \mathrm{~kg} \mathrm{wwt} \cdot \mathrm{m}^{-2}$. The growth rate of Ulva sp. during this period was $0.043 \mathrm{~d}^{-1}$. The grazing rate due to invertebrates was only $0.01 \mathrm{~d}^{-1}$ and no sporulation was observed.

The horizontal drift during the falling tide measured in vertically segmented nets showed that Chaetomorpha sp., Ulva sp. and Zostera sp. had different drift patterns in the water column during transport. A total of $89 \%$ of the Zostera sp. was drifting close to the water surface, while $65 \%$ of the transport of Chaetomorpha spp. took place along the bottom. There was no vertical drifting pattern in the transport of Ulva sp., which was dispersed in the whole water column (figure 9).

Correlations between simulated current velocity and plant drift for each plant group and for all field measurements are presented in figure 10. There was a positive correlation between plant transport and current velocity for both Ulva sp. $\left(r^{2}=0.86\right)$ and Chaetomorpha sp. $\left(r^{2}=0.82\right)$, while the transport of Zostera sp. $\left(r^{2}=0.2\right)$ was not significantly related to the water current velocity. This correlation between the macroalgae drift and the current velocity indicated that advective transport was a major loss process from the study area. The advective transport of the rooted macrophytes did not show any clear correlation to the current velocity, most probably because the sloughed leaves from macrophytes, unlike macroalgae, float on the water surface. In this case, the wind drag is acting 
M.R. Flindt et al.

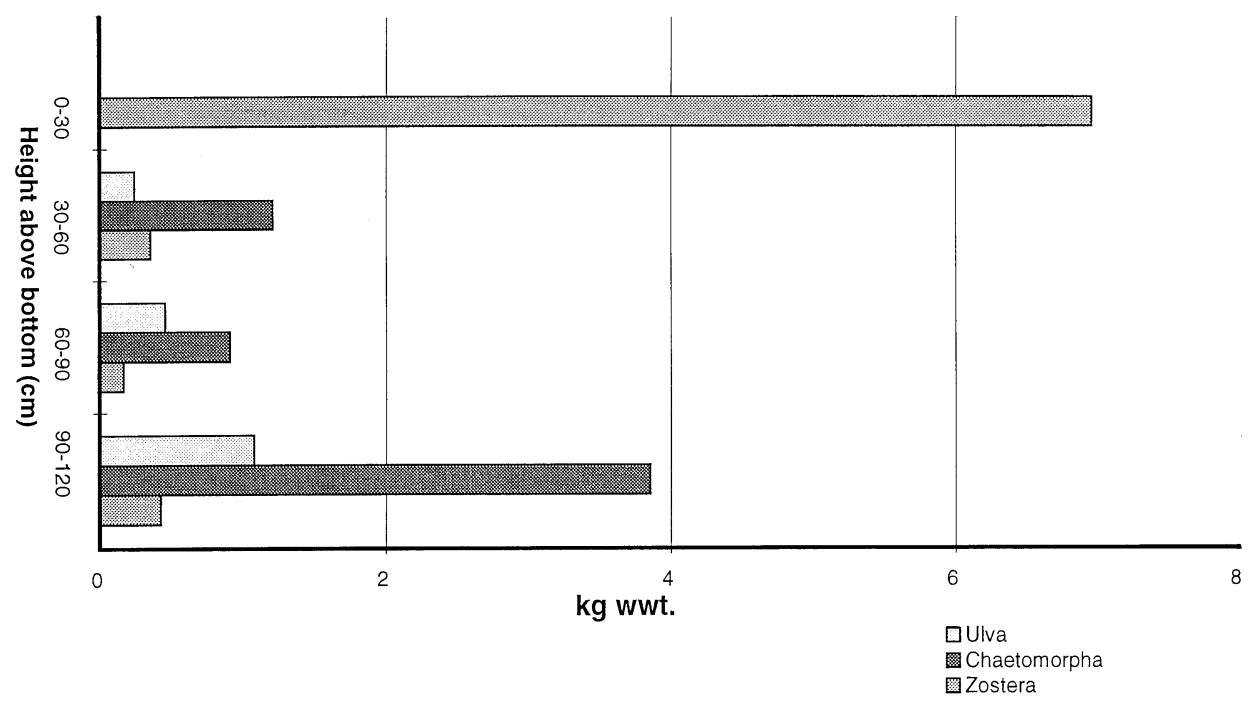

Figure 9. Vertical drift pattern of the macrophytes 29-30 May 1995 in the Venice Lagoon.

directly and therefore the wind direction is the primary driving factor for the drift direction. It would also be expected that the sloughing of leaves from rooted macrophytes would not only be controlled by current velocities but also dependent on the age of the leaves and the physiological condition of the plant.

Comparing the advective transport of dissolved inorganic nitrogen and phosphorus with organic carbon, total nitrogen and total phosphorus in the suspended matter with carbon, nitrogen and phosphorus in the drifting plant tissue, it was possible to calculate the contribution of each fraction to the total mass balance. The results are shown for the nitrogen transport from one outflow situation in figure 11. The advective transport of dissolved inorganic nutrients accounted for $0.4 \%$ of the total transport of nitrogen and $1.1 \%$ of the total transport of phosphorus. The transport of suspended matter accounted for $6 \%$ of the particulate carbon and $3.6 \%$ of inorganic and particulate nitrogen and $3.9 \%$ of inorganic and particulate

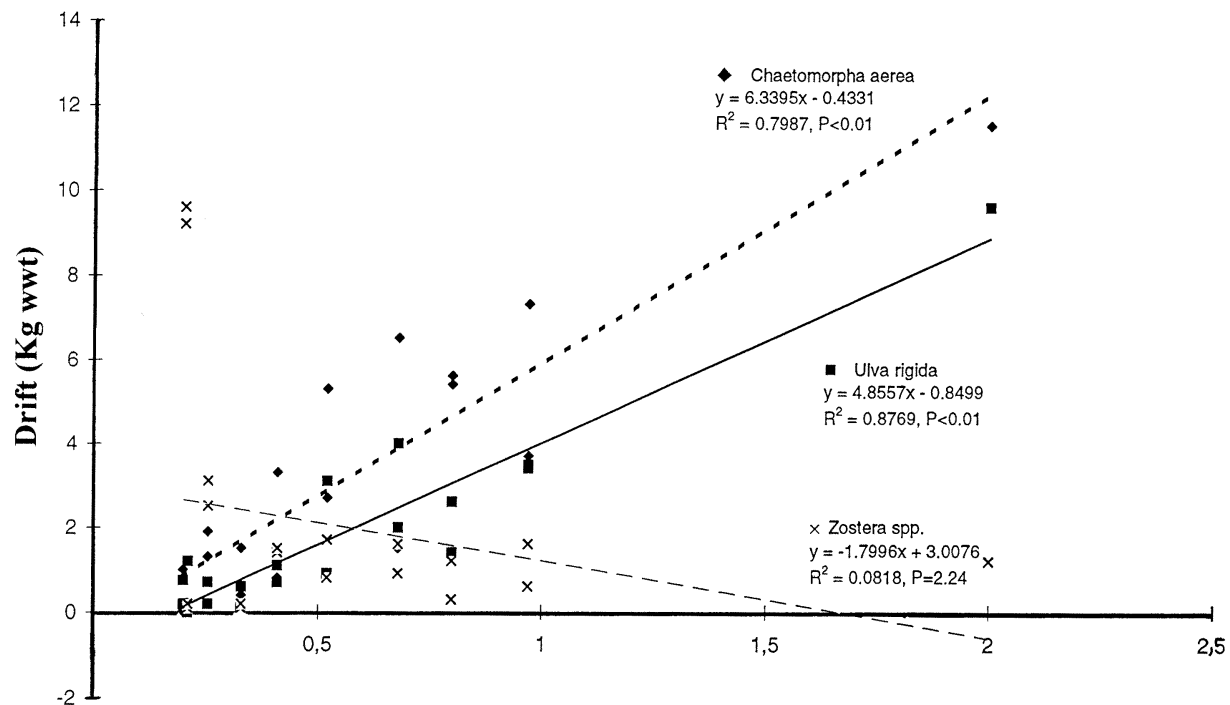

Current velocity $\left(\mathrm{m} \mathrm{s}^{-1}\right)$
Figure 10. Regressions between drift and the current velocity of Chaetomorpha aerea, Ulva rigida and Zostera sp. from 29 May to 28 June 1995 (Venice Lagoon). 


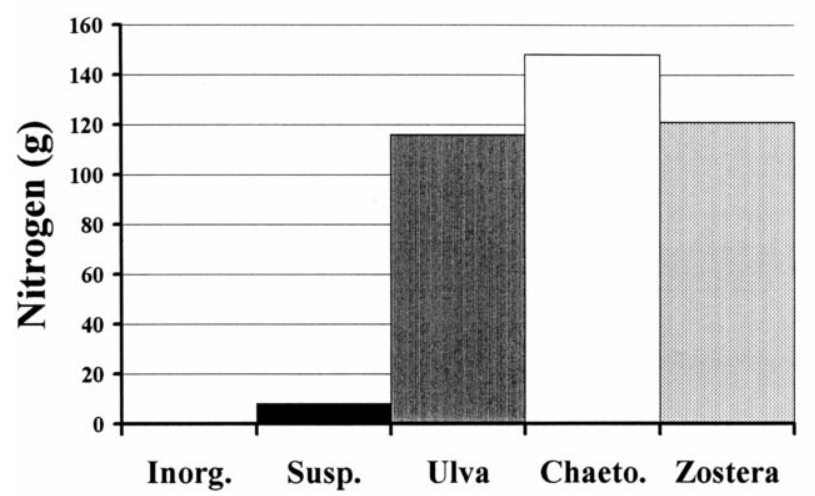

Figure 11. Transport through the net of nitrogen as dissolved inorganic nitrogen, in the suspended particulate matter and in Chaetomorpha aerea, Ulva rigida and Zostera sp. from 29-30 May 1995 (Venice Lagoon).

phosphorus. Thus, most of the elemental transport was drifting aquatic plants. These accounted for $94 \%$ of the carbon, $95 \%$ of the nitrogen and $91 \%$ of the phosphorus transport. Thus, the main loss processes for aquatic macrophytes at the study site was advective transport whereas sporulation and grazing were not important. More than $90 \%$ of the total advective export of carbon, nitrogen and phosphorus was in the form of drifting macrophytes and macrodetritus. The importance of transport as a major loss process for macrophytes are in the process of being verified in two new studies, a shallow eutrified coastal area in Denmark and once more in the Venice Lagoon, this time with measurements during both inflow and outflow situations. These preliminary results show that the export of nutrients bound in macrophytes or macrodetritus is not balanced with an equivalent import. In fact, a large net export is found.

\section{REFERENCES}

[1] Azeiteiro U.M.M., Marques J.C., Temporal and spatial structure in the suprabenthic community of a shallow estuary (western Portugal: Mondego river estuary), Acta Oecol. 20 (1999) 333-342.

[2] Barko J.W., Gunnison D., Carpenter S.R., Sediment interactions with submersed macrophyte growth and community dynamics, Aquat. Bot. 41 (1991) 41-65.

[3] Berner E.K., Berner R.A., Global Environment. Water, Air and Geochemical Cycles, Prentice-Hall Inc., 1996, 376 p.
[4] Borum J., The quantitative role of macrophytes, epiphytes, and phytoplankton under different nutrient conditions in Roskilde Fjord, Denmark, in: Proceedings of the International Symposium on Aquatic Macrophytes, Nijmegen, the Nederlands, 1983, pp. 35-40.

[5] Borum J., Development of epiphytic communities on eelgrass (Zostera marina) along a nutrient gradient in a Danish estuary, Mar. Biol. 87 (1985) 211-218.

[6] Borum J., Ecology of coastal waters and their response to eutrophication, in: Sand-Jensen K., Pedersen O. (Eds.), Freshwater Biology, Gads Forlag, Copenhagen, Denmark, 1997, chapter 7 .

[7] Cabral J.A., Pardal M.A., Lopes R.J., Múrias T., Marques J.C., The impact of macroalgal blooms on the use of the intertidal area and feeding behaviour of waders (Charadrii) in the Mondego estuary (west Portugal), Acta Oecol. 20 (1999) 417-427.

[8] Caffrey J.M., Kemp W.M., Nitrogen cycling in sediments with estuarine populations of Potamogeton perfoliatus and Zostera marina, Mar. Ecol. Prog. Ser. 66 (1990) 147-160.

[9] Carignan R., Kalff J., Phosphorus sources for aquatic weeds: water or sediment, Science 207 (1980) 987-989.

[10] Chambers P.A., Prepas E.E., Bothwell M.L., Hamilton H.R., Roots versus shoots in nutrient uptake by aquatic macrophytes in flowing waters, Can. J. Fish. Aquat. Sci. 46 (1989) 435-439.

[11] Enriques E., Duarte C.M., Sand-Jensen K., Patterns in decomposition rates among photosynthetic organisms: the importance of detritus C:N:P content, Oecologia 94 (1993) $457-471$.

[12] Fenchel T., Aspects of the decomposition of seagrasses, in: McRoy C.P., Felfferich C. (Eds.), Seagrass Ecosystems, Marine Science, vol. 14, Dekker, 1977.

[13] Flindt M.R., Measurements of nutrient fluxes and mass balances by on-line in situ dialysis in a Zostera marina $\mathrm{L}$. bed culture, Verein 25 (1994) 2259-2264.

[14] Geertz-Hansen O.G., Sand-Jensen K., Søsalat er reguleret af græsning, Vand og Miljø 4 (1992) 109-113.

[15] Geertz-Hansen O.G., Sand-Jensen K., Hansen D.F., Christiansen A., Growth and grazing control of abundance of the marine macroalga, Ulva lactuca L. in a eutrophic Danish estuary, Aquat. Bot. 46 (1993) 101-109.

[16] Godshalk G.L., Wetzel R.G., Decomposition of aquatic angiosperms. III. Zostera marina L. and a conceptual model of decomposition, Aquat. Bot. 5 (1978) 329-354.

[17] Hansen F.G., Fordeling af makroalger samt vækst af Ulva lactuca og Fucus vesiculosus langs en næringsstofgradient i Roskilde Fjord, M.Sc. thesis, University of Copenhagen, Denmark, 1984.

[18] Harlin M.M., Thorne-Miller B., Nutrient of seagrass in a Rhode Island coastal lagoon, Mar. Biol. 65 (1981) 221-229.

[19] Harrison P.G., Detrital processing in seagrass systems: A review of factors affecting decay rates, remineralization and detritivory, Aquat. Bot. 23 (1989) 263-288.

[20] Lillebø A.I., Flindt M.R., Pardal M.A., Marques J.C., The effect of macrofauna, meiofauna and microfauna on the degradation of Spartina maritima detritus from a salt marsh area, Acta Oecol. 20 (1999) 249-258.

[21] Lillebø A.I., Pardal M.A., Marques J.C., Population structure, dynamics and production of Hydrobia ulvae (Pennant) (Mollusca: Prosobranchia) along an eutrophication gradient in the Mondego estuary (Portugal), Acta Oecol. 20 (1999) 289-304. 
[22] Mann K.H., Macrophyte production and detritus food chains in coastal waters, Mem. Ist. Ital. Idrobiol. Dott Marco Marchi 29 (1972) 353-383.

[23] Mann K.H., Decomposition of marine macrophytes, in: Anderson J.M. (Ed.), The Role of Terrestrial and Aquatic Organisms in the Decomposition Process, The 17th Symposium of the British Ecological Society, 1975, pp. 247-267.

[24] Martins I., Oliveira J.M., Flindt M.R., Marques J.C., The effect of salinity on the growth rate of the macroalgae Enteromorpha intestinalis (Chlorophyta) in the Mondego estuary (west Portugal), Acta Oecol. 20 (1999) 259-265.

[25] Mazé R.A., Domínguez J., Pérez-Cardenal D., Diet of $\mathrm{Li}$ pophrys pholis (L.) (Teleostei, Blenniidae) in Cantabrian coastal waters (Spain), Acta Oecol. 20 (1999) 435-448.

[26] Mucha A.P., Costa M.H., Macrozoobenthic community structure in two Portuguese estuaries: Relationship with organic enrichment and nutrient gradients, Acta Oecol. 20 (1999) 363-376.

[27] Nichols D.S., Keeney D.R., Nitrogen nutrition of Myriophyllum spicatum: Variation of plant tissue nitrogen concentration with season and site in Lake Wingra, Freshw. Biol. 6 (1976) 137-144.

[28] Nichols D.S., Keeney D.R., Nitrogen nutrition of Myriophyllum spicatum uptake and translocation of ${ }^{15} \mathrm{~N}$ by shoots and roots, Freshw. Biol. 6 (1976) 144-154.

[29] Niesenbaum R.A., The ecology of sporulation by the macroalgae Ulva Lactuca L. (Chlorophycae), Aquat. Bot. 32 (1988) 155-166.

[30] Odum E.P., de la Cruz A.A., Particulate organic detritus in a Georgia salt marsh-estuarine ecosystem, in: Lauff G.H. (Ed.), Estuaries, AAAS Publication 83, American Association for the Advancement of Science, Washington DC, 1967, pp. 383-388.
[31] Pardal M.A., Impacto da entrofizaçâo nas comunidades macrobentónicas do braço sul do estuário do Mondego (Portugal), Ph.D. thesis, Univ. of Coimbra, Portugal, 1998.

[32] Pedersen M.F., Borum J., Nitrogen dynamics of eelgrass Zostera marina during a late summer period of high growth and low nutrient availability, Mar. Ecol. Prog. Ser. 80 (1992) $65-73$.

[33] Sand-Jensen K., Borum J., Interactions among phytoplankton, periphyton, and macrophytes in temperate freshwaters and estuaries, Aquat. Bot. 41 (1991) 137-176.

[34] Sfriso A., Pavoni B., Marcomini A., Orio A.A., Macroalgae, nutrient cycles, and pollutants in the Lagoon of Venice, Estuaries 15 (1992) 517-528.

[35] Short R.M., McRoy C.P., Nitrogen uptake by leaves and roots of the seagrass Zostera marina L., Bot. Mar. 27 (1984) 547-555.

[36] Smart R.M., Barko J.W., Laboratory culture of submersed freshwater macrophytes on natural sediments, Aquat. Bot. 21 (1985) 251-263.

[37] Tubbs C.R., Tubbs J.M., The distribution of Zostera and its exploitation by wildfowl in the Solent, Southern England, Aquat. Bot. 15 (1983) 223-239.

[38] Viaroli P., Pugnetti A., Ferrari I., Ulva rigida growth and decomposition processes and related effects on nitrogen and phosphorus cycles in a coastal lagoon (Saccadi Goro, Po River Delta), 25th Proc. European Marine Biology, 1991, pp. 77-83.

[39] Viaroli P., Bartoli M., Bondavalli C., Christian R.R., Giordani G., Naldi M., Macrophyte communities and their impact on benthic fluxes of oxygen, sulphide and nutrients in shallow eutrophic environments, Hydrobiologia 329 (1996) 105-119.

[40] Uchida M., Numaguchi K., Formation of protoplasmic detritus with characteristics favorable as food for secondary animals during microbial decomposition of Ulva pertusa (Chlorophyta) frond, J. Mar. Biotechnol. 4 (1996) 200-206. 